\title{
Skeletal reorganisation affects geochemical signals, exemplified in the stylasterid hydrocoral Errina dabneyi (Azores Archipelago)
}

\author{
Max Wisshak ${ }^{1, *}$, Matthias López Correa ${ }^{1}$, Helmut Zibrowius $^{2}$, \\ Joachim Jakobsen ${ }^{3}$, André Freiwald ${ }^{1}$ \\ ${ }^{1}$ GeoZentrum Nordbayern, Universität Erlangen-Nürnberg, Loewenichstr. 28, 91054 Erlangen, Germany \\ ${ }^{2}$ Station Marine d'Endoume, Rue Batterie des Lions, 13007 Marseille, France \\ ${ }^{3}$ Rebikoff-Niggeler Foundation, Rocha Vermelha, 9900-451 Horta, Faial, Azores, Portugal
}

\begin{abstract}
The pure white fans of the stylasterid Errina dabneyi are a conspicuous feature on the upper bathyal slopes in Azorean waters and were documented and recovered alive with the aid of a submersible in the southern Faial Channel. Etched vacuum-epoxy-casts of the aragonite skeleton, studied by scanning electron microscopy, reveal the 3-dimensional internal architecture comprising coenosarc canal meshwork, dactylopores, gastropores and ampullae. Near the surface, the canals are narrow and interconnected in a regular 3-dimensional meshwork. Deeper inside the canals are less abundant, more irregular and wider. This pattern implies that the skeletal architecture is modified during growth, with more central canals being enlarged by dissolution, and other canals, gastropores and dactylopores in turn being filled with aragonite reprecipitates. The skeleton is primarily composed of irregular spherulitic aggregates and overprinting during growth is evident from ghost structures in the form of successive semi-spherulitic infill of former canals. Due to differential dissolution and reprecipitation, this internal rebuild process inevitably involves an alteration of initial geochemical signatures such as stable isotope ratios $\left(\delta^{18} \mathrm{O}\right.$ and $\left.\delta^{13} \mathrm{C}\right)$, trace element signals and the distribution of radiogenic isotopes of carbon and uranium. This has to be taken into account when applying radiometric dating techniques and when using stylasterids as a geochemical archive.
\end{abstract}

KEY WORDS: Hydrozoa - Stylasteridae - Microstructure - Biomineralisation - Coenosarc canals · Geochemical signals $\cdot$ Stable isotopes $\cdot$ Epoxy-casting technique

Resale or republication not permitted without written consent of the publisher

\section{INTRODUCTION}

Coral skeletons, both solid calcareous and proteinaceous structures, are promising geochemical archives, for instance with respect to (palaeo)temperatures deduced from their oxygen and carbon stable isotope composition (reviewed in Swart \& Leder 1996). This is based on their sessile nature, an often distinct incremental growth pattern and comparatively low growth rates, especially in deep water, with some species reaching centennial and even millennial life spans (Druffel et al. 1995, Risk et al. 2002, Andrews et al. 2005, Roark et al. 2009). The skeletal aragonite of deepwater scleractinians can be precisely dated with U-Th and radiocarbon techniques to reconstruct the timing of ventilation changes in deep and intermediate water masses (e.g. Cheng et al. 2000, Frank et al. 2004).

However, the use of corals as geochemical archives to reconstruct past temperature and productivity regimes in the deep oceans also presents various methodological and interpretational pitfalls, most of which are related to biological fractionation processes known as 'vital effects' (e.g. Smith et al. 2000, Cohen et al. 2006). This applies to many azooxanthellate coldwater scleractinians, including the intensely studied Lophelia pertusa Linnaeus, 1758 (Blamart et al. 2005, Lutringer et al. 2005). On a quest for other suitable deep-water coral species, geochemical research now 
includes primnoid (Heikoop et al. 2002, Sherwood et al. 2005, Noé et al. 2007), coralliid (Weinbauer et al. 2000) and isidid octocorals (Thresher et al. 2009), as well as zoanthids (Druffel et al. 1995) and antipatharians (Love et al. 2007, Williams et al. 2007).

Another promising, but up to now little studied, group of corals are calcareous hydrocorals, specifically stylasterids. In a pioneering paper, Weber \& Woodhead (1972) found that tropical shallow-water hydrozoans, contrary to most scleractinians, actually precipitate their aragonitic skeleton close to equilibrium with seawater. They investigated representatives of the stylasterid genera Stylaster and Distichopora, alongside Millepora. Results by Mienis (2008) indicate that this is also true to some degree for deep-water $S$. gemmascens (Esper, 1794) from the Rockall Trough (NW Atlantic). Likewise, preliminary results from Andrus et al. (2007) show the deep-water S. erubescens Pourtalès, 1868 from the Blake Plateau (N Atlantic) records stable isotopes in equilibrium with (or in uniform offset from) seawater, showing a sinusoidal variation related to apparent incremental banding.

In the present study, we critically evaluate the suitability of stylasterids for geochemical analysesexemplified by Errina dabneyi (Pourtalès, 1871) from the upper bathyal slope of the Azores Archipelago. This evaluation is based on an investigation of its skeletal architecture, the deduced growth mechanisms and its stable isotope signatures $\left(\delta^{18} \mathrm{O}\right.$ and $\left.\delta^{13} \mathrm{C}\right)$. In fact, stylasterids are characterised by a complicated inner architecture that has to be taken into account. This inner architecture was first analysed and illustrated in a remarkable way by Moseley (1879, 1881), then revisited by Cairns (1983) as the basis for systematic revision requirements. The oldest representatives of the genus Errina are known from the Danian (65 to 61 million yr) deeper water coral limestone of Faxe, Denmark (Bernecker \& Weidlich 1990, Lindner et al. 2008). At present, 26 species of Errina, most from deeper waters, are known worldwide (Cairns 1983). E. dabneyi seems to be endemic to the Azores Archipelago and the adjacent Mid-Atlantic Ridge region (Zibrowius \& Cairns 1992).

\section{MATERIALS AND METHODS}

Documentation and sample recovery. Colonies of Errina dabneyi were videoand photo-documented in situ in the southern Faial Channel during several dives with the research submersible
'LULA' between 2003 and 2008 (Fig. 1, Table 1). A total of 3 specimens were recovered during Dives 117 (2006; see Figs. 4-7A-C,E), 126 (2007) and 136 (2008; see Figs. 2B,C \& 3A-D) in close to $500 \mathrm{~m}$ water depth with the aid of a manipulator and a sampling basket; specimens are herein referred to by their respective dive numbers.

Growth rate analysis. An estimation of the growth rate was obtained via 2 time series of in situ still images, taken over 2 and 5 yr, respectively, from selected Errina colonies (Table 1). One of the photographed specimens (Specimen 136) was subsequently recovered for exact scale determination and later stable isotope analyses, while the other was left in situ for further long-term growth pattern monitoring.

Microstructure analysis. Errina skeletons were vacuum-epoxy-impregnated with Araldite BY158 and Aradur 21 prior to sectioning, grinding and polishing. The skeletal architecture and microstructure was studied by staining with Feigl solution for discrimination of the carbonate mineral phase and CamScan scanning electron microscopy (SEM) of polished gold sputtercoated samples after treatment with $0.1 \mathrm{~mol} \mathrm{l}^{-1} \mathrm{HCl}$ for $30 \mathrm{~s}$. To visualise the internal canal system, the resinimpregnated samples were treated with $\sim 1 \mathrm{~mol} \mathrm{l}^{-1} \mathrm{HCl}$ for up to $1 \mathrm{~h}$ in order to remove part or all of the skeletal carbonate, leaving only the casts of the canals which were then studied with SEM.

Stable isotope analysis. MicroMill (New Wave) technology was applied to obtain high-resolution carbonate powder samples from epoxy resin-embedded (resin non-soluble in phosphoric acid) and slow-speed

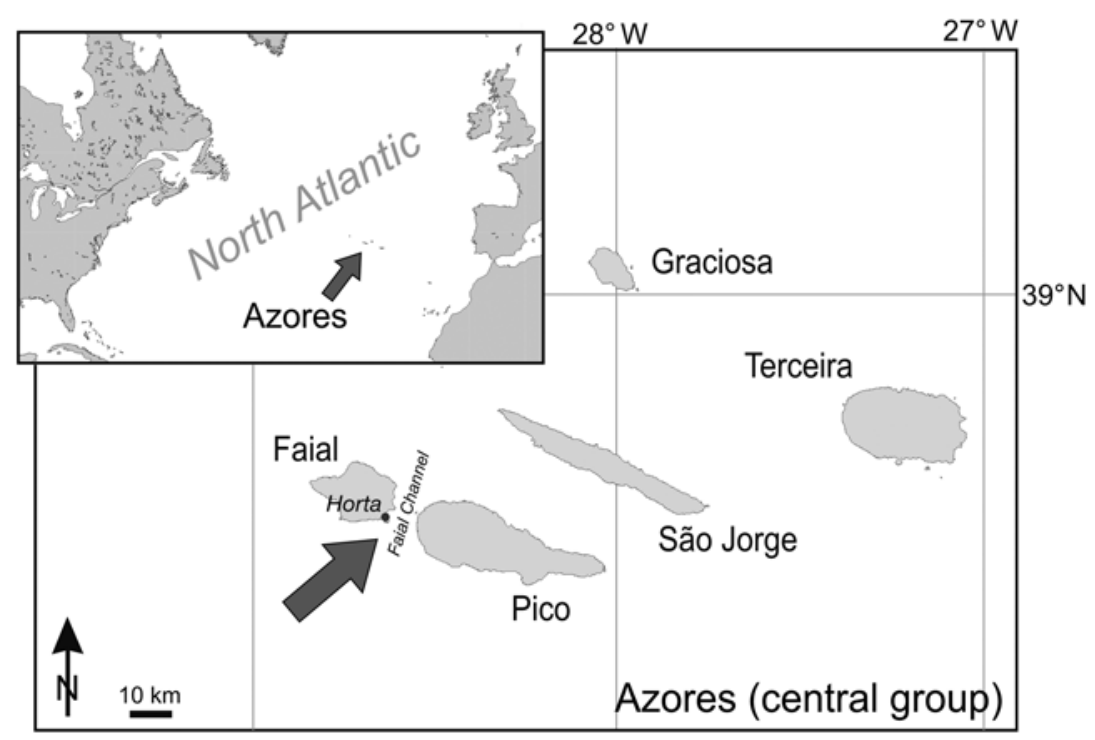

Fig. 1. Location of the Faial Channel between the Islands of Faial and Pico in the central group of the Azores Archipelago. Errina dabneyi was documented and sampled with submersible 'LULA' along the upper bathyal slope of the southern part of this current-enhancing seaway south of Horta 
Table 1. Details of some of the dives from the submersible 'LULA' in the southern Faial Channel where Errina dabneyi was documented or sampled. col.: colony or colonies

\begin{tabular}{|c|c|c|c|c|c|c|c|c|c|}
\hline $\begin{array}{l}\text { Dive } \\
\text { no. }\end{array}$ & $\begin{array}{c}\text { Date } \\
\text { (dd.mm.yy) }\end{array}$ & $\begin{array}{c}\text { Start } \\
\text { Coordinates }\end{array}$ & $\begin{array}{c}\text { Depth } \\
\text { (m) }\end{array}$ & $\begin{array}{l}\text { End - } \\
\text { Coordinates }\end{array}$ & $\begin{array}{c}\text { Depth } \\
\text { (m) }\end{array}$ & Specimens & $\begin{array}{l}\text { Photo/video- } \\
\text { documentation }\end{array}$ & $\begin{array}{l}\text { Water } \\
\text { samples } \\
\text { (depth) }\end{array}$ & $\begin{array}{l}\text { Logger } \\
\text { deployment/ } \\
\text { recovery }\end{array}$ \\
\hline 69 & 21.07 .03 & $\begin{array}{l}38^{\circ} 29.575^{\prime} \mathrm{N} \\
28^{\circ} 38.114^{\prime} \mathrm{W}\end{array}$ & 450 & $\begin{array}{l}38^{\circ} 29.240^{\prime} \mathrm{N} \\
28^{\circ} 37.252^{\prime} \mathrm{W}\end{array}$ & 475 & & $\mathrm{X}$ & & \\
\hline 116 & 13.09 .06 & $\begin{array}{l}38^{\circ} 29.382^{\prime} \mathrm{N} \\
28^{\circ} 37.613^{\prime} \mathrm{W}\end{array}$ & 500 & $\begin{array}{c}38^{\circ} 29.218^{\prime} \mathrm{N} \\
28^{\circ} 37.404^{\prime} \mathrm{W}\end{array}$ & 495 & & $\begin{array}{c}\mathrm{X} \\
(=136)\end{array}$ & & $\mathrm{X}$ \\
\hline 117 & 17.09 .06 & $\begin{array}{l}38^{\circ} 29.100^{\prime} \mathrm{N} \\
28^{\circ} 37.350^{\prime} \mathrm{W}\end{array}$ & 490 & $\begin{array}{l}38^{\circ} 29.400^{\prime} \mathrm{N} \\
28^{\circ} 37.400^{\prime} \mathrm{W}\end{array}$ & 350 & $\begin{array}{l}117 \text { (isotope } \\
\text { transect) }\end{array}$ & X & & \\
\hline 125 & 24.09 .07 & $\begin{array}{l}38^{\circ} 29.218^{\prime} \mathrm{N} \\
28^{\circ} 37.404^{\prime} \mathrm{W}\end{array}$ & 495 & $\begin{array}{l}38^{\circ} 29.510^{\prime} \mathrm{N} \\
28^{\circ} 37.400^{\prime} \mathrm{W}\end{array}$ & 350 & & $\mathrm{X}$ & $\mathrm{X}(500 \mathrm{~m})$ & \\
\hline 126 & 01.10 .07 & $\begin{array}{l}38^{\circ} 29.218^{\prime} \mathrm{N} \\
28^{\circ} 37.404^{\prime} \mathrm{W}\end{array}$ & 495 & $\begin{array}{l}38^{\circ} 29.218^{\prime} \mathrm{N} \\
28^{\circ} 37.404^{\prime} \mathrm{W}\end{array}$ & 495 & 126 & $\begin{array}{c}\mathrm{X} \\
(=136)\end{array}$ & $\mathrm{X}(500 \mathrm{~m})$ & $\mathrm{X}$ \\
\hline 127 & 02.10 .07 & $\begin{array}{l}38^{\circ} 29.773^{\prime} \mathrm{N} \\
28^{\circ} 38.437^{\prime} \mathrm{W}\end{array}$ & 495 & $\begin{array}{l}38^{\circ} 29.773^{\prime} \mathrm{N} \\
28^{\circ} 38.437^{\prime} \mathrm{W}\end{array}$ & 470 & & & $\mathrm{X}(500 \mathrm{~m})$ & \\
\hline 135 & 24.09 .08 & $\begin{array}{l}38^{\circ} 29.208^{\prime} \mathrm{N} \\
28^{\circ} 36.501^{\prime} \mathrm{W}\end{array}$ & 470 & $\begin{array}{l}38^{\circ} 29.524^{\prime} \mathrm{N} \\
28^{\circ} 36.439^{\prime} \mathrm{W}\end{array}$ & 350 & & $\mathrm{X}$ & $\mathrm{X}(500 \mathrm{~m})$ & \\
\hline 136 & 30.09 .08 & $\begin{array}{l}38^{\circ} 29.202^{\prime} \mathrm{N} \\
28^{\circ} 37.394^{\prime} \mathrm{W}\end{array}$ & 470 & $\begin{array}{l}38^{\circ} 29.520^{\prime} \mathrm{N} \\
28^{\circ} 37.600^{\prime} \mathrm{W}\end{array}$ & 350 & $\begin{array}{l}136 \text { (growth } \\
\text { rate analysis) }\end{array}$ & $\begin{array}{c}X \\
(=136)\end{array}$ & & \\
\hline
\end{tabular}

sawed (Bühler IsoMet 1000) sample blocks for the stable isotope analyses $\left(\delta^{18} \mathrm{O}\right.$ and $\left.\delta^{13} \mathrm{C}\right)$. Individual tracks were $\sim 4 \mathrm{~mm}$ in length and $100 \mu \mathrm{m}$ wide with an average spacing of 130 to $140 \mu \mathrm{m}$. To enhance the faint growth increments, as a guide for placement of MicroMill tracks, a polished and briefly etched sample was gold sputter-coated, photographed and the contrast increased with Adobe Photoshop. The $20 \mathrm{~mm}$ long transect across the mid-plane of a basal trunk of a medium-sized (12 cm height) Errina dabneyi colony (Specimen 117) comprised 147 consecutive sampling tracks. Additionally, this and 2 other colonies (Specimens 126 and 136) were sampled along their surface ( $\sim 3 \mathrm{~mm}$ wide and very shallow spot samples) with a hand-held dental drill to screen isotopic differences between contemporaneously grown proximal adult and distal juvenile surfaces. The carbonate powders were reacted with $100 \%$ phosphoric acid (density > 1.9) at $75^{\circ} \mathrm{C}$ using a Kiel III online carbonate preparation line connected to a Thermo-Finnigan MAT 252 mass spectrometer. All values are reported in per mil relative to Vienna-PeeDee Belemnite (V-PDB). The reproducibility $(1 \sigma)$ is better than $\pm 0.04 \%$ for $\delta^{13} \mathrm{C}$ and $\pm 0.05 \%$ o for $\delta^{18} \mathrm{O}$.

\section{RESULTS AND DISCUSSION}

\section{Habitat characteristics and distribution}

Errina dabneyi is a common faunal element on the upper bathyal slope of the southern Faial Channel and was encountered on most of the dives that targeted waters deeper than $\sim 350 \mathrm{~m}$ down to the submersible's diving limit of $500 \mathrm{~m}$ (Fig. 1, Table 1). The highest population density was found at around $450 \mathrm{~m}$ water depth, where this coral occurs on bedrock outcrops that often also bear aggregations of the deep-sea oyster Neopycnodonte zibrowii Gofas, Salas and Taviani in Wisshak et al., 2009 and the cyrtocrinoid Cyathidium foresti Cherbonnier and Guille, 1972 (Wisshak et al. 2009a,b). Most of the previous samples of E. dabneyi from the Azores, including the type material, were recovered from 215 to $500 \mathrm{~m}$ water depth (Zibrowius \& Cairns 1992). Further material stems from the Mid-Atlantic Ridge to the southwest from 1400 to $2200 \mathrm{~m}$ water depth (Zibrowius \& Cairns 1992), but this much greater depth seems strange given the considerable divergence from confirmed records and in situ (submersible) observations in the Azores. E. dabneyi was not among the abundant stylasterid fauna sampled (by the cruise SEAMOUNT 2 in 1993) on Great Meteor and other seamounts situated a few degrees south of the Azores archipelago.

The pure white, densely branched, flabellate colonies are up to $\sim 40 \mathrm{~cm}$ in size and are predominantly found on the more current-exposed ridges and cliff tops, with their concave side facing the current (Fig. 2). Quite often, solitary scleractinians, mainly Desmophyllum dianthus (Esper, 1794) (= Desmophyllum cristagalli Milne-Edwards and Haime, 1848) and Caryophyllia cyathus (Ellis and Solander, 1786), were found attached to the stylasterid fan facing downstream (Fig. 2B,C). The base and the current-facing side of the fan is less often colonised by scleractinians but is frequently overgrown by sponges (Fig. 3). 

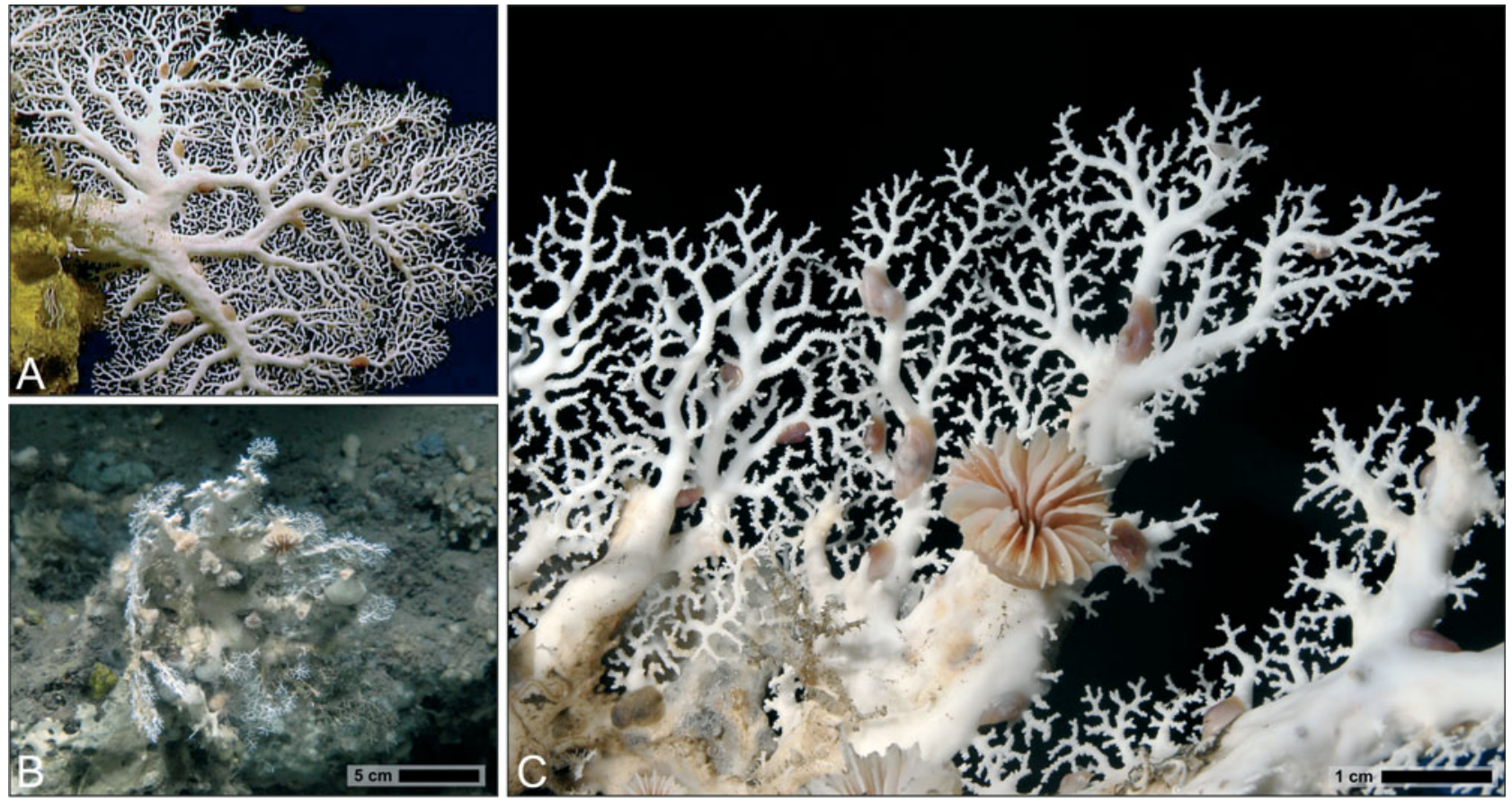

Fig. 2. Errina dabneyi. Pure white, fan-shaped colonies in $~ 500 \mathrm{~m}$ water depth in the southern Faial Channel. (A) Convex side of a large colony $\sim 30 \mathrm{~cm}$ in size. Note the many individuals of the symbiotic gastropod Pedicularia sicula (Dive 69, $475 \mathrm{~m}$ ). (B) Concave side of another large colony, colonised by many solitary scleractinians of the species Desmophyllum dianthus (= Desmophyllum cristagalli) and Caryophyllia cyathus alongside various sponge species (Dive 136, $490 \mathrm{~m}$ ). (C) Detail of the same colony taken immediately after recovery from the seafloor (Specimen 136)

A symbiont regularly found occupying the more distal branches on both sides of the fans is the prosobranch gastropod Pedicularia sicula Swainson, 1840 (Fig. 4A-C). Representatives of the genus Pedicularia are common obligate symbionts on stylasterids worldwide, including in the NE Atlantic. The snail typically deposits a layer of lime under which the sealed-off stylasterid skeleton cannot grow in thickness, leading to a characteristic attachment scar (Fig. 4C) on which the foot of the snail adheres efficiently (Zibrowius \& Cairns 1992, Goud \& Hoeksema 2001).

\section{Growth rates}

While pronounced destruction and loss of branches was visible in both monitored colonies (Fig. 3C,F), the extent of skeletal growth at the outer margin of the fan was minute and of the magnitude of only a few millimetres per year. One monitored colony (Specimen 136; Figs. 2B,C \& 3A-D) was sampled after the last photo was taken, allowing for direct measurement of the areas where the colony had remained intact; in places, branches had grown 4 to $6 \mathrm{~mm}$ in length per year. In the case of the other monitored colony (not sampled; Fig. 3E,F), the partial damage was possibly caused by an unfortunate manoeuvre with the submersible only minutes after the first photo was taken. In the $5 \mathrm{yr}$ and 2 mo since, the colony regenerated branches $<2 \mathrm{~cm}$ in length, even though precise scaling was impossible because the colony was left in situ for further long-term observations. Potential natural hazards for the fragile colonies were captured on film when a crab walked across a colony (Specimen 136; Fig. 3B, arrow) and a large ray almost hit the same colony during Dive 126 (Fig. 3D), possibly distracted by the lights or electromagnetic field of the submersible. For statistically sound growth rates of Errina dabneyi, further in situ time series - preferentially supported by calcein or manganese tagging experiments - are needed to gain a better understanding of how they vary with respect to colony size, position, and recovery from partial mortality.

The only other stylasterid studied with respect to growth rate is Errina novaezelandiae Hickson, 1912. Chong \& Stratford (2002) obtained growth rates (branch lengthening) from calcein tagging and stereo photography and found positive values of $3.1 \pm 0.6$ and $8.0 \pm 0.9 \mathrm{~mm} \mathrm{yr}^{-1}$, respectively. They also recorded considerable negative growth caused by breakage and bioerosion, leading to a net growth rate of $2.7 \pm 1.1 \mathrm{~mm}$ 

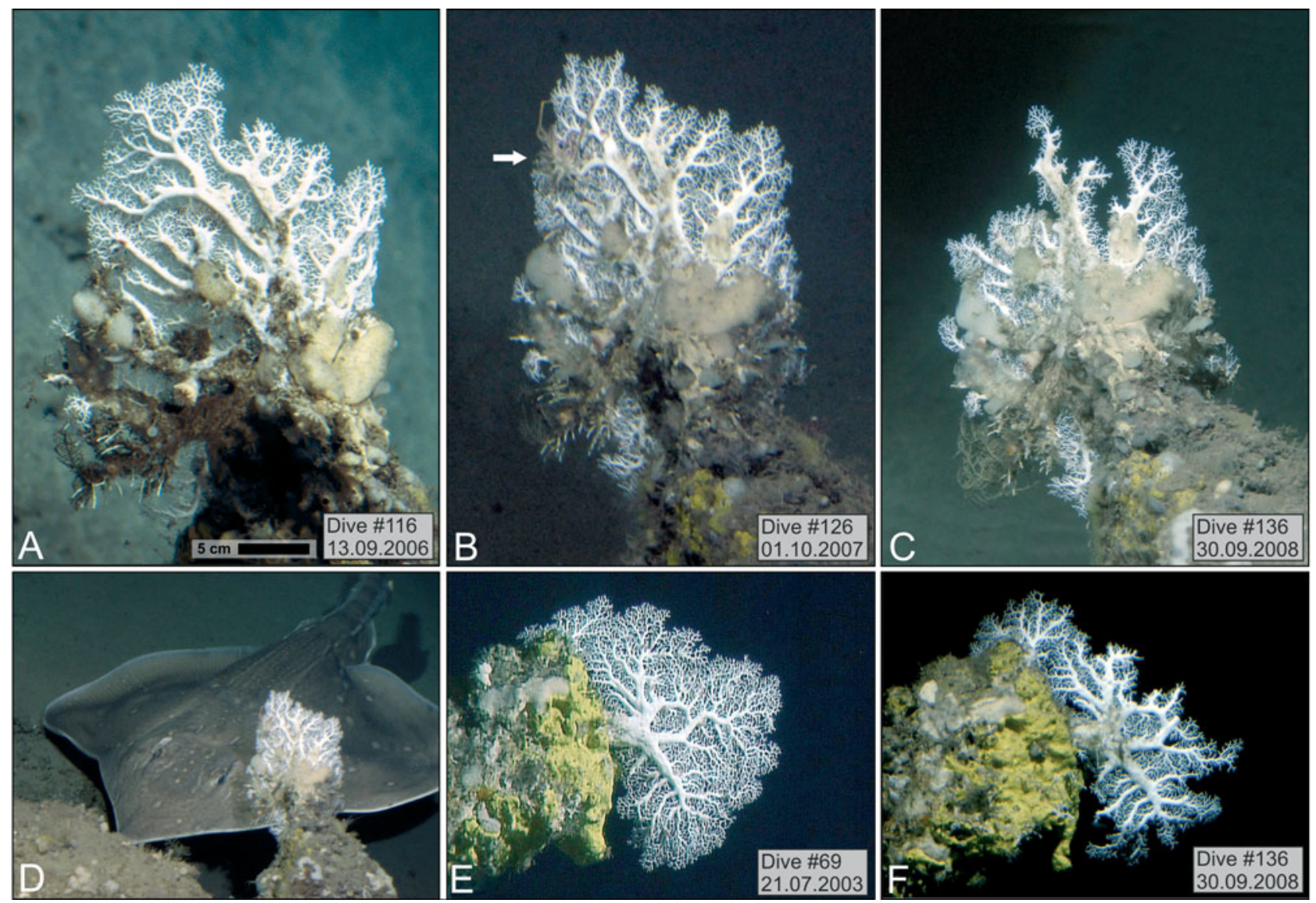

Fig. 3. Errina dabneyi. Time series of 2 colonies, both $\sim 30 \mathrm{~cm}$ in size, indicating low linear growth rates in the magnitude of a few $\mathrm{mm}$ per year. (A-D) Current-facing side of a colony (Specimen 136; 500 m water depth) photographed in 2006,2007 and 2008. Only minimal growth is seen along the periphery of the colony, whereas breakage is evident, possibly caused by crustaceans (arrow in B) or a fish such as the ray almost hitting the colony on Dive 126 (D). (E,F) Time series of another colony photographed in 2003 and 2008 ( 500 m water depth). Minute new branches have grown where main branches were broken

$\mathrm{yr}^{-1}$. For the same species, Miller et al. (2004) found

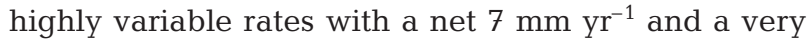
high maximum rate of $680 \mathrm{~mm} \mathrm{yr}^{-1}$, largely independent of colony size. However, this New Zealand species is primarily calcitic in mineralogy (Cairns \& Macintyre 1992) and was studied in a shallow-water fjord setting within the reach of scuba diving (15 to $40 \mathrm{~m}$ ). In this setting, higher nutrient fluxes can be presumed to exist than on the bathyal slopes in Azorean waters, which may explain the higher growth rates.

\section{Skeletal architecture}

Errina dabneyi colonies grow as pure white, uniplanar (and upstream slightly concave) fans up to $40 \mathrm{~cm}$ wide. The dactylopores and gastropores are crowded on terminal branches (Fig. 4D,E), whereas the more basal stems bear only scarce coenostreal papillae (Fig. 4F).
The vacuum-epoxy casting technique, adopted and modified from microbioerosion investigations (after Wisshak 2006, modified from Golubic et al. 1970), proved useful for the SEM study of the 3-dimensional internal architecture of the coenosarc canal meshwork, dactylopores, gastropores and ampullae (Figs. 5 \& 6). The method is simple, time-efficient, cheap and bears good potential for studying permeable canal systems, pores and the like in calcareous skeletons.

In the peripheral layer of the branches, near the surface, the canals are $\sim 10 \mu \mathrm{m}$ wide and branch in a regular pattern with a mesh width of around $100 \mu \mathrm{m}$ (Fig. 5). Deeper inside, the canals are more irregular and wider, some running along the central axis of the branches (Fig. 5D,G,I). In the thinner peripheral branches, the gastropores with the central gastrostyle are primarily oriented distally at oblique angles (Fig. 5A). They are connected to the canal meshwork at their walls and particularly at their base (Fig. 5B,C). In a more proximal position and in the more peripheral 

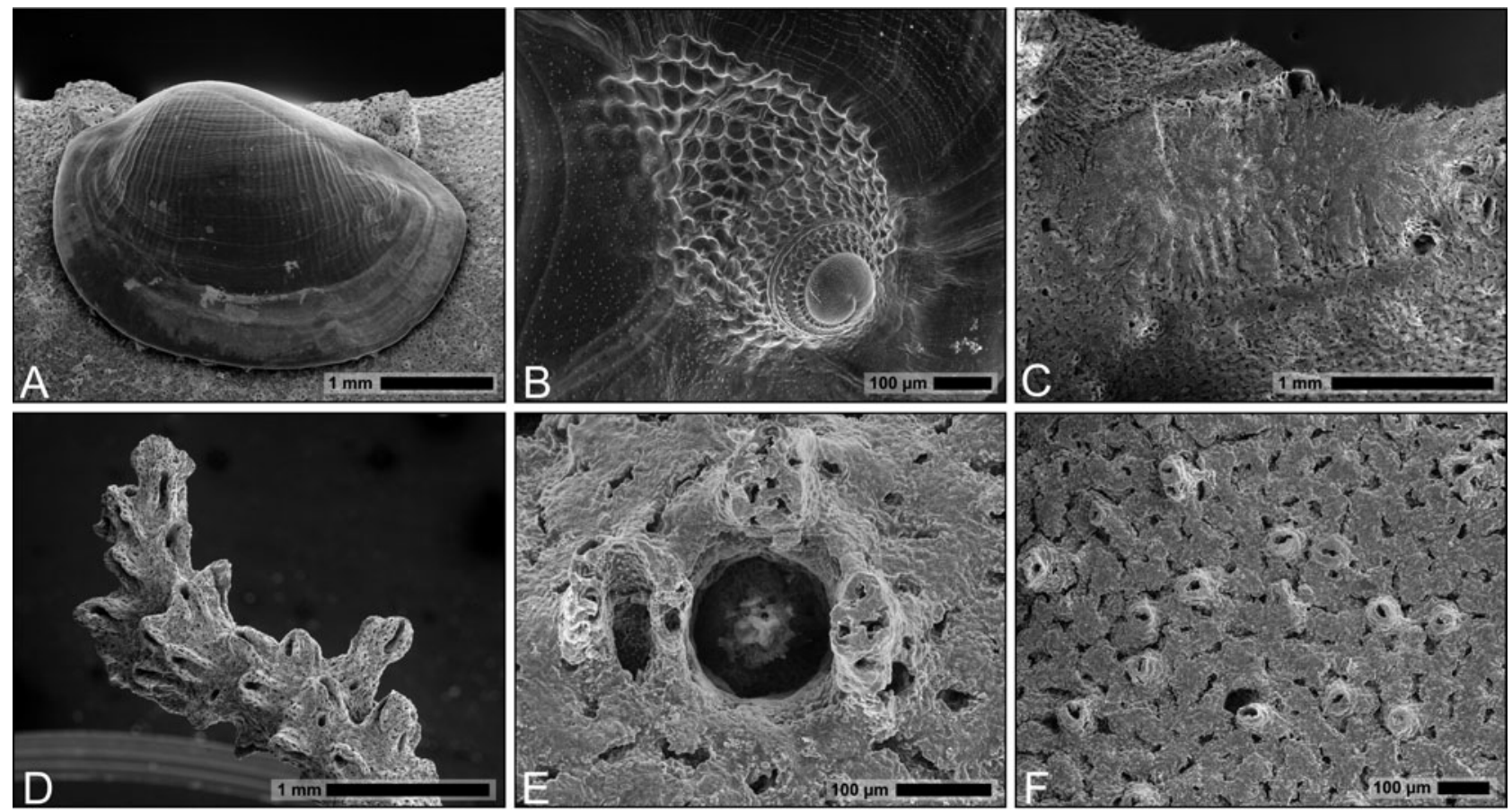

Fig. 4. Errina dabneyi and Pedicularia sicula. SEM images illustrating morphological details of Specimen 117 and its symbiont. (A) Symbiotic prosobranch gastropod P. sicula and (B) close-up of the early ontogenetic shell of a juvenile. (C) Characteristic attachment scar of $P$. sicula. (D) Terminal branch of E. dabneyi bearing many dactylopores. (E) Typical circular gastropore and its central gastrostyle. (F) Coenosteum of a more proximal branch devoid of dactylopores and gastropores but bearing many small coenostreal papillae

layer, the branches contain subspherical to irregularly shaped ampullae, $300 \mu \mathrm{m}$ and more in diameter, which are connected to the wider canals (Fig. 5D,F).

\section{Skeletal reorganisation}

Analysis of the patterns of the 3-dimensional coenosarc canal meshwork indicates that the skeletal architecture undergoes modification during growth. This follows simple geometric reasons. With growth in thickness of the branches, the formerly superficial meshwork of narrow canals is, with progressing growth, located deeper inside where then, however, wider canals are observed. Accordingly, some of the central canals have become enlarged by dissolution of skeletal material, whereas at the same time other canals have been filled-in with aragonite reprecipitates. Jointly, during this process the dactylopores and gastropores are entirely resorbed. Likewise, the ampullae are filled or remain open but embedded while new active ampullae are formed closer to the surface.

This process of transformation is recorded in the microstructure of the stylasterid skeleton (Fig. 6). The aragonitic nature of the skeleton was positively tested via Feigl solution and is primarily composed of fulland semi-spherulitic aggregates (Fig. 6A,B), the typical microstructure of stylasterids (Fenninger \& Flajs 1974). This structure is overprinted during growth, as indicated by ghost structures in the form of successive semi-spherulitic in-fill of former canals (Fig. 6B-E). Where side branches were filled with reprecipitates (Fig. 6D), the plug-like ending can be seen from inside the canal (Fig. 6F). Still to be resolved is whether the dissolved skeletal material is actively transported by the live tissues to the sites of reprecipitation, potentially a more efficient biomineralisation process.

The proximal thicker trunk of the colony often consists of brownish, dead coenosteum that may undergo rejuvenescence by new, white coenosteum spreading over from the more peripheral living regions. Distinct growth breaks are thus formed which are characterised by partly preserved peripheral canal meshwork (Fig. 6G,H). Sometimes encrusting epibionts and traces of microbioerosion are thus immurated by the overflow of new coenosteum. This indicates that the coenosteum, once dead (i.e. devoid of live tissues in the canal meshwork), is not or only partly subjected to further restructuring. These growth breaks may have the appearance of cyclic increments; however, this is not their actual nature. In the denser centre of the basal 

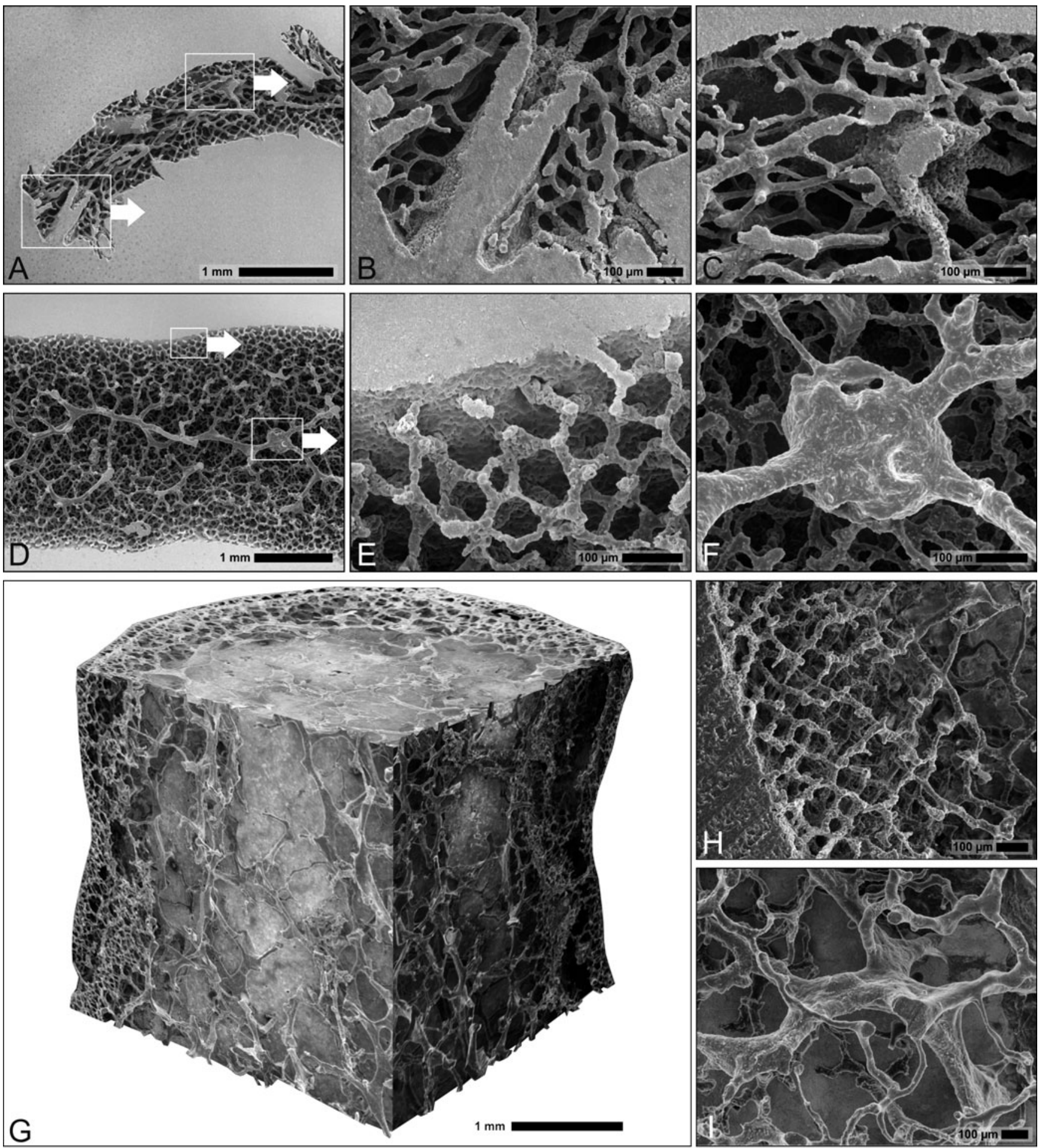

Fig. 5. Errina dabneyi. SEM images of Specimen 117 that was vacuum-resin-embedded and decalcified with hydrochloric acid, illustrating the 3-dimensional internal architecture. (A-C) Terminal branch bearing a number of gastropores and dactylopores, integrated into a dense meshwork of coenosarc canals. (B) Sectioned gastropore exposing the gastrostyle. (C) Gastropore base with radiating connections to the canal meshwork. (D-F) Sub-terminal branch without gastropores or dactylopores but showing ampullae and recording the development of wider canals in the centre, replacing the former fine meshwork of peripheral canals. (E) Peripheral coenosarc meshwork. (F) Ampullae. (G-I) Proximal stem (only partially etched, retaining part of the skeletal matrix; SEM composite image) showing denser central part with irregularly formed and oriented large canals and the fine meshwork restricted to the periphery. (H) Peripheral and (I) central meshwork 

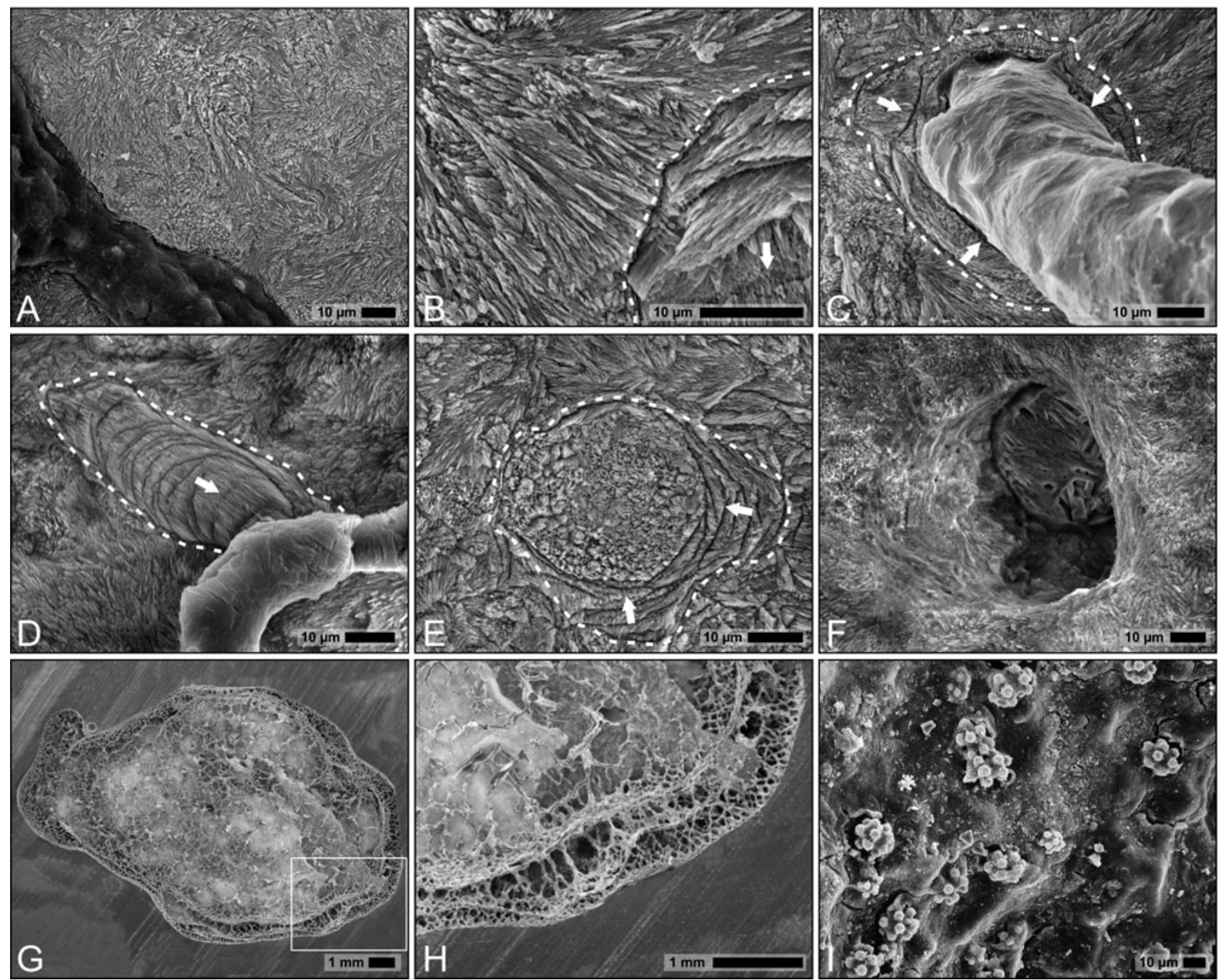

Fig. 6. Errina dabneyi. SEM analysis of the microstructure of the aragonitic skeleton (Specimen 117). (A,B) Irregular spherulitic aggregates. (B-E) Ghost structures in form of successive semi-spherulitic infill of former canals; former tunnel delineated by dashed line and direction of infill indicated by arrows. (F) Terminus of a side branch filled with reprecipitates as seen from inside a canal. $(\mathrm{G}, \mathrm{H})$ Apparent incrementation in the periphery of the basal stem, formed by new skeletal material being formed on dead coenosteum, retaining part of the former peripheral meshwork. (I) Spiculae of a boring hadromerid sponge, commonly found tunnelling the dense centre of the basal stems

trunk, only a faint incrementation can be detected (enhanced in Fig. 7B). The centre of the trunk is, however, often found intensely bored by hadromerid sponges (Fig. 6I) which may also extend upwards into the living parts of the colony.

\section{Stable isotope signature}

In order to evaluate to what degree Errina dabneyi precipitates its stable isotope composition of aragonite in equilibrium with the ambient seawater, a complete seasonal cycle of in situ temperatures was logged in high resolution, and the stable isotope composition of the ambient seawater in $500 \mathrm{~m}$ water depth was moni- tored (Wisshak et al. 2009a). Temperature was stable with an annual mean of $12.3 \pm 0.25^{\circ} \mathrm{C}$, monthly means differed by $<0.4^{\circ} \mathrm{C}$, short-term fluctuations were on the order of $1{ }^{\circ} \mathrm{C}\left(\min .=10.86^{\circ} \mathrm{C}, \max .=13.52^{\circ} \mathrm{C}\right)$ and the $\delta^{18} \mathrm{O}_{\text {water }}$ varied between 0.47 and $0.64 \%$ with a mean of $0.54 \pm 0.06 \%$ relative to V-SMOW (Vienna-Standard Mean Ocean Water) (Wisshak et al. 2009a). Using these background data, an expected mean equilibrium at $2.40 \% \delta^{18} \mathrm{O}$ relative to V-PDB can be calculated via the equation of Grossman \& $\mathrm{Ku}$ (1986): $\mathrm{T}=20.6-4.34$ $\left(\delta^{18} \mathrm{O}_{\text {arag }}-\delta^{18} \mathrm{O}_{\text {water }}\right)$, where $\mathrm{T}$ is temperature $\left({ }^{\circ} \mathrm{C}\right)$. Considering the standard deviation of both parameters, a skeletal $\delta^{18} \mathrm{O}$ range of 2.29 to $2.52 \%$ would be expected. For the unlikely case that the extreme temperature and $\delta^{18} \mathrm{O}_{\text {water }}$ values are reflected in the iso- 

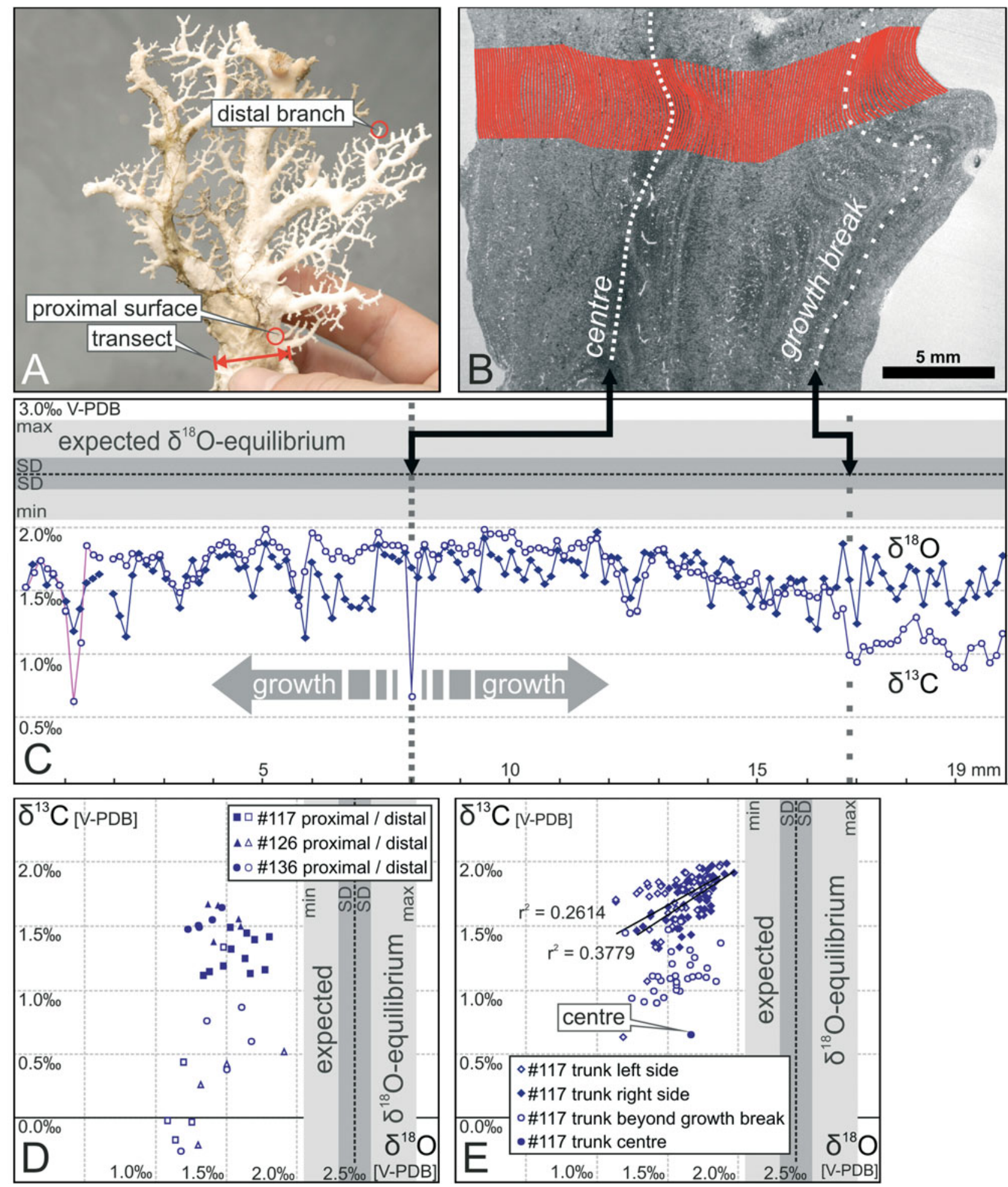

Fig. 7. Errina dabneyi. Stable isotope $\left(\delta^{18} \mathrm{O}\right.$ and $\left.\delta^{13} \mathrm{C}\right)$ analysis of 3 skeletons (Specimens 117, 126 and 136). (A) Medium-sized colony (Specimen 117, $490 \mathrm{~m}$ ) with the position of surface samples and the orientation of the high-resolution transect. (B) MicroMill transect in a longitudinal section across the basal stem of the colony. (C) Stable isotope transect showing an overall ontogenetic decrease in $\delta^{13} \mathrm{C}$ after a rapid initial increase, and constant fluctuations in $\delta^{18} \mathrm{O}$ at both sides of the growth centre with poor high-resolution symmetry. (D) Cross plot of $\delta^{18} \mathrm{O}$ versus $\delta^{13} \mathrm{C}$ of terminal branches versus more proximal surfaces in 3 colonies sampled during Dives 117, 126 and 136 in $~ 500 \mathrm{~m}$ water depth. (E) Cross plot of $\delta^{18} \mathrm{O}$ versus $\delta^{13} \mathrm{C}$ from the transect showing low correlation and moderate range. Note the depleted $\delta^{13} \mathrm{C}$ values of the centre and the zone beyond the growth break 
topic record, a maximum $\delta^{18} \mathrm{O}$ range of 2.06 to $2.83 \%$ would be expected (Fig. 7C-E).

The actual mean oxygen stable isotope values of Errina dabneyi $\left(1.5 \pm 0.4 \%\right.$ o $\delta^{18} \mathrm{O}$ V-PDB; Specimens 117,126 and $136 ; \mathrm{n}=182$ ) show a negative offset from the expected equilibrium by $\sim 0.9 \%$, with the heaviest values closest to, but still $0.4 \%$ offset and outside, the extreme equilibrium range (Fig. 7D,E). The overall range $(\sim 0.9 \%)$ of the oxygen values is moderate. Hence, unlike shallow-water Millepora, Stylaster and Distichopora which were reported to precipitate aragonite in equilibrium with seawater (Weber \& Woodhead 1972), E. dabneyi is prone to a moderate biological fractionation process leading to an average $0.9 \%$ negative offset in $\delta^{18} \mathrm{O}$. However, none of the environmental settings for the previously studied milleporid and stylasterid hydrocorals comprised such constant conditions as encountered in the upper bathyal Azorean waters; therefore, seasonal variations could have complicated a concise equilibrium assessment. Weber \& Woodhead (1972) also considered all their sampling sites as uniform with respect to the ambient seawater $\delta^{18} \mathrm{O}$ composition and a less accurate temperature equation was used. It is therefore possible that similar biological fractionation might still be unveiled in the previously investigated hydrocorals. Indeed, the negative $0.9 \%$ shift in $\delta^{18} \mathrm{O}$ from the expected equilibrium values for skeletal aragonite has also been found in S. gemmascens from the southwestern Rockall Trough (Mienis 2008, her Fig. 7.3). But the absolute range $(\sim 0.7 \%)$ of skeletal $\delta^{18} \mathrm{O}$ in $S$. gemmascens roughly coincides with the estimated range calculated from the ambient temperatures of 6.2 to $9.8^{\circ} \mathrm{C}$, and with the range observed for the Azorean E. dabneyi. A similar, possibly constant, negative offset from equilibrium has also been invoked by Andrus et al. (2007) for S. erubescens from the Blake Plateau (NW Atlantic).

Another prerequisite for the application of an organism as a reliable high-resolution geochemical archive is the reproducibility of the signal across coeval time series of incremental banding. Hence sample transects on both sides of the growth axis should show a clear symmetry as an essential pattern. But here, the above outlined factor of skeletal reorganisation comes into play. The high-resolution transect across the main trunk of Specimen 117 shows a mean of $1.6 \pm 0.3 \%$ $\delta^{18} \mathrm{O}$ V-PDB with short-term fluctuations of up to $0.5 \%$ (Fig. $7 \mathrm{C}, \mathrm{E}$ ). In light of the logged stable temperature, this short-term amplitude must be considered far too high for reliably mirroring temperature fluctuations.

The basal trunk shows in its geochemical pattern 3 different zones: (1) the $\delta^{13} \mathrm{C}$-depleted centre, (2) the somewhat symmetric layers on either side of the centre, and (3) following a growth break, a rejuvenescent zone with higher $\delta^{18} \mathrm{O}$ and very low $\delta^{13} \mathrm{C}$ composition (Fig. 7B,C). The centre is characterised by a single point with a depleted $\delta^{13} \mathrm{C}$ composition of $0.7 \%$ V-PDB, which we interpret as a buried relict of the earliest ontogeny. The immediately adjacent central layers show much heavier $\delta^{13} \mathrm{C}$ compositions of 1.8 to $2.0 \% \mathrm{~V}$ PDB. To both sides of the centre, a slight decrease in $\delta^{18} \mathrm{O}$ was found but no high-resolution symmetry can be recognised. The $\delta^{13} \mathrm{C}$ values exhibit a mean of $1.6 \pm$ $0.2 \%$ V-PDB with maximum values clustering just below $2.0 \%$ V-PDB and an overall range of close to $1.5 \%$. This range is largely due to a general ontogenetic decrease in $\delta^{13} \mathrm{C}$ following the rapid ontogenetic increase in the earliest ontogeny, and shows a moderate degree of symmetry. This overriding ontogenetic trend is visible despite the skeletal reorganisation, and is coherent with the observed general difference between proximal and distal surface portions (see below). As a consequence of this ontogenetic imprint, the overall correlation between $\delta^{18} \mathrm{O}$ and $\delta^{13} \mathrm{C}$ is poor $\left(r^{2}=0.26\right.$ and 0.38 for the 2 sides), and the slopes of the regressions are considerably inconsistent in different ontogenetic parts of the skeleton, most likely as a result of metabolic effects on the $\delta^{13} \mathrm{C}$ values, thus complicating an application of the lines technique (after Smith et al. 2000) for overcoming the 'vital effect'. Conspicuous non-symmetric drops of the $\delta^{13} \mathrm{C}$ composition below the ontogenetic trend to values between 0.6 to $1.5 \%$ are considered as remnants of former depleted surface compositions, which have only partly been modified by the skeletal reorganization. This also implies that the reorganization is not affecting each portion of the skeleton in the same way and with the same efficiency. On one side of the transect, an outer $3 \mathrm{~mm}$ of younger skeleton was precipitated following a distinct growth break. This layer is also visible as whitish zone on the right side of the basal trunk (Fig. 7A). Its oxygen isotope values are slightly higher than in the adjacent adult trunk (Fig. 7C). The respective much lower $\delta^{13} \mathrm{C}$ depicts the variability in the external layer, prior to the modification during the ubiquitous skeletal reorganization.

Further evidence for the skeletal reorganization comes from a comparison between the isotopic composition of the surface layer, from contemporaneous proximal (adult) to distal (juvenile) portions (Specimens 117, 126 and 136, $\mathrm{n}=35$; Fig. 7D), with the isotopic composition across the internal layers from the high-resolution MicroMill transect in the basal trunk (Specimen 117, $\mathrm{n}=147$; Fig. 7E). While the composition of oxygen isotopes shows similar ranges and absolute values between 1.2 and $2.0 \%{ }^{18} \mathrm{O}$ V-PDB in all skeletal portions, there are strong differences for carbon isotopes. The most depleted $\delta^{13} \mathrm{C}$ is encountered in the distal terminal branches, with similar 
extreme values of $\sim-0.3 \% \delta^{13} \mathrm{C}$ V-PDB. Likewise, there is a clear difference between these surface layers in distal portions and contemporaneous proximal surface layers, which exhibit the heaviest external $\delta^{13} \mathrm{C}$-values in each colony. Even heavier $\delta^{13} \mathrm{C}$ compositions are encountered in the internal layers-a fact which clearly highlights later alteration of the isotopic composition during the skeletal reorganization, which has been verified by our microstructural investigations.

\section{Implications for geochemical signals}

In conclusion, the present investigation on Errina dabneyi suggests that the internal reorganisation of the coenosarcs canal meshwork with considerable differential dissolution and reprecipitation alters not only initial stable isotope signals, but most likely also trace element signatures, limiting the value of stylasterids with a similar growth pattern as high-resolution geochemical archives. Stable isotope and trace element transects must be expected to have undergone a certain degree of signal averaging and modification. However, since the major zone of reprecipitation-the infill of the dense peripheral canal meshwork-is steadily moving outwards, following the zone of initial precipitation, overall trends in the geochemical signals may be partially retained, such as the ontogenetic decrease in $\delta^{13} \mathrm{C}$ as shown above. The bulk geochemical composition of the skeleton might also bear meaningful environmental signals, such as the bulk $\delta^{18} \mathrm{O}$ when considering the relatively constant negative offset of $0.9 \%$ observed in Errina dabneyi and other stylasterids. However, it needs to be taken into account that stylasterid architecture and the degree of skeletal reorganisation may vary among different species, for instance the shallow-water species Distichopora robusta Lindner, Cairns \& Guzman, 2004, which has more robust branches and poorly defined pore rows (Lindner et al. 2004).

The skeletal reorganisation likely also affects the distribution of radiogenic isotopes such as ${ }^{14} \mathrm{C},{ }^{210} \mathrm{~Pb}$, ${ }^{230} \mathrm{Th}$ and ${ }^{238} \mathrm{U}$. Hence, radiometric dating as a prerequisite for time-referencing the geochemical archive must be expected to yield underestimated ages. This has been suggested for Paragorgia arborea (Linnaeus, 1758), which is very likely affected by a similar skeletal reconstruction, leading to a potential modification of its radiocarbon composition (Sherwood \& Edinger 2009, their Fig. 6). Furthermore, precise timereferencing of geochemical transects through the basal stem of a stylasterid will be complicated by the potential occurrence of growth breaks (no cyclic increments as discussed above) of unknown duration close to the periphery.
Acknowledgements. F. Lorenz (Buseck, Germany) kindly confirmed the taxonomic assessment of Pedicularia sicula. The Rebikoff-Niggeler Foundation (Horta, Azores) is thanked for their commitment and their valuable tool LULA. The anonymous referees are thanked for their valuable comments and suggestions. This project is financially supported by the Deutsche Forschungsgemeinschaft (to A.F. and M.W.; DFG Fr 1134/12-1).

\section{LITERATURE CITED}

Andrews AH, Cailliet GM, Kerr LA, Coale KH, Lundstrom C, DeVogelaere AP (2005) Investigations of age and growth for three deep-sea corals from Davidson seamount off central California. In: Freiwald A, Roberts JM (eds) Cold-water corals and ecosystems. Springer, Berlin, p 1021-1038

Andrus CFT, Romanek CS, Sedberry GR (2007) Incremental growth in a deep-sea hydrocoral. 1st Int Sclerochronology Conf, St. Petersburg, FL, 17-21 July 2007, p 3 (Abstract)

Bernecker M, Weidlich O (1990) The Danian (Paleocene) coral limestone of Fakse, Denmark: a model for ancient aphotic, azooxanthellate coral mounds. Facies 22:103-138

Blamart D, Rollion-Bard C, Cuif JP, Juillet-Leclerc A, Lutringer A, vanWeering TCE, Henriet JP (2005) C and O isotopes in a deep-sea coral (Lophelia pertusa) related to skeletal microstructure. In: Freiwald A, Roberts JM (eds) Cold-water corals and ecosystems. Springer, Berlin, p 1005-1020

Cairns SD (1983) A generic revision of the Stylasterina (Coelenterata: Hydrozoa). Part 1. Description of the genera. Bull Mar Sci 33:427-508

Cairns SD, Macintyre IG (1992) Phylogenetic implications of calcium carbonate mineralogy in the Stylasteridae (Cnidaria: Hydrozoa). Palaios 7:96-107

Cheng H, Adkins J, Edwards RL, Boyle EA (2000) U-Th dating of deep-sea corals. Geochim Cosmochim Acta 64: $2401-2416$

Chong AK, Stratford P (2002) Underwater digital stereoobservations technique for red hydrocoral study. Photogramm Eng Remote Sens 68:745-751

Cohen AL, Gaetani GA, Lundälv T, Corliss BH, George RY (2006) Compositional variability in a cold-water scleractinian, Lophelia pertusa: new insights into 'vital effects'. Geochem Geophys Geosyst 7:Q12004, doi:10.1029/ 2006GC001354

> Druffel ERM, Griffin S, Witter A, Nelson E, Suthon J, Kashagarian M, Vogel J (1995) Gerardia: Bristlecone pine of the deep sea? Geochim Cosmochim Acta 59:5031-5036

Fenninger A, Flajs G (1974) Zur Mikrostruktur rezenter und fossiler Hydrozoa (On the microstructure of recent and fossil Hydrozoa). Biomineralisation 7:69-99

Frank N, Paterne M, Ayliffe L, van Weering T, Henriet JP, Blamart D (2004) Eastern North Atlantic deep-sea corals: tracing upper intermediate water $\delta^{14} \mathrm{C}$ during the Holocene. Earth Planet Sci Lett 219:297-309

Golubic S, Brent G, Le Campion T (1970) Scanning electron microscopy of endolithic algae and fungi using a multipurpose casting-embedding technique. Lethaia 3:203-209

Goud J, Hoeksema BW (2001) Pedicularia vanderlandi spec. nov., a symbiotic snail (Caenogastropoda: Ovulidae) on the hydrocoral Distichopora vervoorti Cairns \& Hoeksema, 1998 (Hydrozoa: Stylasteridae) from Bali, Indonesia. Zool Verh 334:77-97

Grossman EL, Ku TL (1986) Oxygen and carbon isotope fractionation in biogenic aragonite: temperature effects. 
Chem Geol 59:59-74

Heikoop JM, Hickmott DD, Risk MJ, Shearer CK, Atudorei V (2002) Potential climate signals from the deep-sea gorgonian coral Primnoa resedaeformis. Hydrobiologia 471: $117-124$

Lindner A, Cairns SD, Guzman HM (2004) Distichopora robusta sp. nov., the first shallow-water stylasterid (Cnidaria: Hydrozoa: Stylasteridae) from the tropical eastern Pacific. J Mar Biol Assoc UK 84:943-947

Lindner A, Cairns SD, Cunningham CW (2008) From offshore to onshore: multiple origins of shallow-water corals from deep-sea ancestors. PLoS ONE 3:e2429

Love MS, Yoklavich MM, Black BA, Andrews AH (2007) Age of black coral (Antipathes dendrochristos) colonies, with notes on associated invertebrate species. Bull Mar Sci 80: 391-400

Lutringer A, Blamart D, Frank N, Labeyrie L (2005) Paleotemperatures from deep-sea corals, scale effects. In: Freiwald A, Murray JM (eds) Cold-water corals and ecosystems. Springer, Berlin, p 1081-1096

Mienis F (2008) Environmental constraints on cold-water coral growth and carbonate mound formation. $\mathrm{PhD}$ thesis, Vrije Universiteit Den Burg, Amsterdam

Miller KJ, Mundy CN, Chadderton WL (2004) Ecological and genetic evidence of the vulnerability of the shallow-water populations of the stylasterid hydrocoral Errina novaezelandiae in New Zealand's fjords. Aquat Conserv 14:75-94

Moseley HN (1879) On the structure of the Stylasteridae, a family of the hydroid stony corals. Philos Trans R Soc Lond 169:425-503

Moseley HN (1881) Report on certain hydroid, alcyonarian, and madreporarian corals procured during the voyage of H.M.S. Challenger. In: Thomson CW, Murray J (eds) Report on the scientific results of the voyage of the H.M.S. Challenger during the years 1873-76. Zoology - Vol. 2. Eyre \& Spottiswoode, London, p 1-248

- Noé S, Lembke-Jene L, Reveillaud J, Freiwald A (2007) Microstructure, growth banding and age determination of a primnoid gorgonian skeleton (Octocorallia) from the late Younger Dryas to earliest Holocene of the Bay of Biscay. Facies 53:177-188

Risk MJ, Heikoop JM, Snow MG, Beukens R (2002) Lifespans and growth patterns of two deep-sea corals: Primnoa resedaeformis and Desmophyllum cristagalli. Hydrobiologia 471:125-131

Roark EB, Guilderson TP, Dunbar RB, Fallon SJ, Mucciarone

Submitted: February 11, 2009; Accepted: May 27, 2009
DA (2009) Extreme longevity in proteinaceous deep-sea corals. Proc Natl Acad Sci USA 106:5204-5208

Sherwood OA, Edinger E (2009) Ages and growth rates of some deep-sea gorgonian and anthipatharian corals of Newfoundland and Labrador. Can J Fish Aquat Sci 66: $142-152$

Sherwood OA, Heikoop JM, Sinclair DJ, Scott DB, Risk MJ, Shearer C, Azetsu-Scott K (2005) Skeletal Mg/Ca in Primnoa resedaeformis: relationship to temperature. In: Freiwald A, Murray JM (eds) Cold-water corals and ecosystems. Springer, Berlin, p 1061-1079

Smith JE, Schwarcz HP, Risk MJ, McConnaughey TA, Keller N (2000) Palaeotemperatures from deep-sea corals: overcoming 'vital effects'. Palaios 15:25-32

Swart PK, Leder JL (1996) The utility of stable isotopic signatures in coral skeletons. Paleontol Soc Pap 1:249-291

Thresher RE, MacRae CM, Wilson NC, Fallon S (2009) Feasibility of age determination of deep-water bamboo corals (Gorgonacea; Isididae) from annual cycles in skeletal composition. Deep-Sea Res I 56:442-449

Weber JN, Woodhead PMJ (1972) Stable isotope ratio variations in non-scleractinian coelenterate carbonates as a function of temperature. Mar Biol 15:293-297

Weinbauer MG, Brandstätter F, Velimirov B (2000) On the potential use of magnesium and strontium concentrations as ecological indicators in the calcite skeleton of the red coral (Corallium rubrum). Mar Biol 137:801-809

Williams B, Risk MJ, Ross SW, Sulak KJ (2007) Stable isotope data from deep-water antipatharians: 400-year records from the southeastern coast of the United States of America. Bull Mar Sci 81:437-447

Wisshak M (2006) High-latitude bioerosion: the Kosterfjord experiment. Lect Notes Earth Sci 109:1-202

> Wisshak M, López Correa M, Gofas S, Salas C, Taviani M, Jakobsen J, Freiwald A (2009a) Shell architecture, element composition, and stable isotope signature of the giant deep-sea oyster Neopycnodonte zibrowii sp. n. from the NE Atlantic. Deep-Sea Res I 56:374-407

Wisshak M, Neumann C, Jakobsen J, Freiwald A (2009b) The 'living-fossil community' of the cyrtocrinoid Cyathidium foresti and the deep-sea oyster Neopycnodonte zibrowii (Azores Archipelago). Palaeogeogr Palaeoclimatol Palaeoecol 271:77-83

Zibrowius H, Cairns SD (1992) Revision of the northeast Atlantic and Mediterranean Stylasteridae (Cnidaria: Hydrozoa). Mém Mus Natn Hist Nat A 153:1-136

Proofs received from author(s): September 15, 2009 